\title{
Elevated alpha-fetoprotein in benign/borderline liver masses in children
}

\section{Çocuklarda benign/borderline karaciğer kitlelerinde yükselmiş alfa-fetoprotein Doğan KÖSE, ' Cengiz EROL, ${ }^{2}$ Yavuz KÖKSAL ${ }^{3}$}

'Department of Pediatrics, Division of Hematology and Oncology, Selcuk University Faculty of Medicine, Konya; ${ }^{2}$ Department of Radiology, Medipol University Faculty of Medicine, Istanbul;

${ }^{3}$ Department of Pediatrics, Division of Hematology and Oncology, Selcuk University Faculty of Medicine, Konya

\section{OBJECTIVES}

The purpose of this retrospective study is to share the data of the patients with high alpha-fetoprotein and benign/borderline liver mass with literature.

\section{METHODS}

Between 2006 and 2012, 5 of our patients were diagnosed with benign/borderline liver mass in connection with high alphafetoprotein.

\section{RESULTS}

During the diagnostic procedure, alpha-fetoprotein values of our patients were varying between 123-4905 U/L. While one of the patients diagnosed with hemangioendothelioma was transferred for liver transplantation, the other passed away during the early stages under steroid treatment. After observing malign cells in tissue biopsy, chemotherapy was started for the patient diagnosed with mesenchymal hamartoma and the mass was removed completely. It is currently being monitored and is free of any diseases. Patients, who were diagnosed with hemangioma and focal nodular hyperplasia, were monitored without receiving any treatment.

\section{CONCLUSION}

Since it is possible to observe high alpha-fetoprotein in nonmalign liver masses, tissue diagnosis must be confirmed before starting treatment.

Key words: Alpha-fetoprotein; focal nodular hyperplasia; hemangioendothelioma; liver hemangioma; mesenchymal hamartoma.

\section{AMAÇ}

$\mathrm{Bu}$ geriye dönük çalışma ile, alfa-fetoprotein yüksekliği ve benign/borderline karaciğer kitlesi olan hastalarımızın literatürle paylaşılması amaçlandı.

\section{GEREÇ VE YÖNTEM}

2006-2012 tarihlerinde, beş hasta alfa-fetoprotein yüksekliği ile giden benign/borderline karaciğer kitlesi tanısı aldı.

\section{BULGULAR}

Hastalarımızın tanı anındaki alfa-fetoprotein değerleri 1234905 U/L arasında değişiyordu. Hemanjiyoendotelyoma tanısı alan iki hastadan birisi karaciğer nakli için sevk edilirken, diğeri steroid tedavisi altında erken dönemde kaybedildi. Mezankimal hamartom tanısı alan hastaya, doku biyopsisinde malign hücre görülmesi üzerine kemoterapi başlandı, tedavi sonrası küçülen kitle tamamen çıkarıldı ve halen hastalıksız olarak izlenmektedir. Hemanjiyom ve fokal nodüler hiperplazi tanılı hastalar ise herhangi bir tedavi uygulanmadan izleme alındı.

\section{SONUÇ}

Non-malign karaciğer kitlelerinde de alfa-fetoprotein yüksekliği görülebildiğinden tedavi başlanmadan önce doku tanısı mutlaka kesinleştirilmelidir.

Anahtar sözcükler: Alfa-fetoprotein; fokal nodüler hiperplazi, hemanjiyoendotelyom; karaciğer hemanjiyomu; mezankimal hamartom. 
Alpha-fetoprotein (AFP) is a protein and produced by the yolk sac and the liver during fetal development which is thought to be the fetal form of serum albumin. An elevated AFP level is seen in endodermal sinus tumor, hepatoblastoma, and hepatocellular carcinoma. Also, AFP may be elevated by pancreatic and gastrointestinal malignancies, lung cancers, and benign liver conditions such as hepatic dysfunction and cirrhosis. ${ }^{[1]}$

Mildly high AFP levels can be seen in some benign liver masses including mesenchymal hamartoma, hepatic hemangioendothelioma and focal nodular hyperplasia of the liver. ${ }^{[2-4]}$

The aim of this study was to evaluate the elevated AFP in benign liver masses.

\section{MATERIALS AND METHODS}

In this study, five patients, who had applied to our center between 2006 and 2012 and had non-malign liver mass with elevated AFP, were evaluated. Three of the patients had benign and two of them had borderline (hemangioendothelioma) masses. The patients received routine physical examinations, laboratory investigations which included complete blood count, liver function tests and AFP. They also underwent imaging studies including chest radiography, abdominal US, CT and/or MRI.

\section{RESULTS}

The clinical features of the five patients are given in Table 1. ${ }^{[5]}$ There were three boys and two girls with a median age of 6 months (range 1-12 months) at the time that the liver mass was diagnosed. At the time of the diagnosis, AFP levels were between 123 $\mathrm{U} / \mathrm{L}$ and $4905 \mathrm{U} / \mathrm{L}$ (median $2736 \mathrm{U} / \mathrm{L}$ ). The masses ranging from $11 \mathrm{~mm}$ to $28 \mathrm{~cm}$ were detected during screening studies. Two patients were diagnosed with hemangioendothelioma, 1 patient had mesenchymal hamartoma of the liver, one patient had hemangioma and another one was diagnosed with focal nodular hyperplasia through histopathological examination. One of the patients with hemangioendothelioma was referred to another center for liver transplantation, but the other one died during the early follow-up while under steroid treatment. In the patient who had hamartoma with high AFP levels, fine needle aspiration biopsy revealed ma-

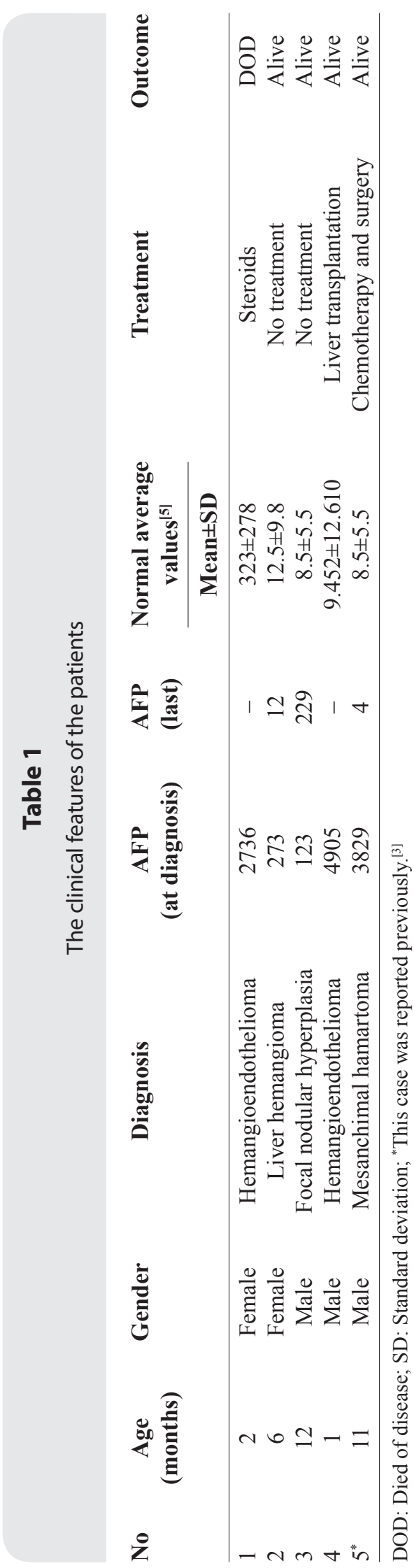


lign cells; therefore, the patient was thought to have primary liver malignancy and cisplatin-adriamicin regimen had begun. After the treatment, the mass in the liver was shrunk and totally excised surgically. After the pathologic evaluation, the final diagnosis was hamartoma; thus, no other treatment was performed and he is still disease-free and under follow-up. The patients with hemangioma and focal nodular hyperplasia are still under follow-up without receiving any treatment.

\section{DISCUSSION}

AFP, an oncofetal glycoprotein, is produced in the yolk sac, the liver, and the gastrointestinal tract during embryo- and fetogenesis. Elevated AFP levels can be determined in malignant tumors including hepatic epithelial tumors (hepatoblastoma, hepatocellular carcinoma), germ cell tumor (yolk sac tumor, immature teratoma), pancreticoblastoma, retinoblastoma, teratomatous nephroblastoma, adenocarcinoma of the gastrointestinal tract, bronchial carcinoma and bladder carcinoma. ${ }^{[6]}$

In childhood hepatic tumors, the elevated AFP level rates of hepatoblastoma, hepatocellular carcinoma and fibrolamellar variant are $60-70 \%, 50 \%$ and $10 \%$ respectively. ${ }^{[7]}$

The undulant AFP course in patients with germ cell tumors during follow-up was assessed by Aydin et al. ${ }^{[8]}$ They concluded that without a demonstrable tumor, the small amplitude undulations may only require a careful follow-up. However, it should be kept in mind that despite the decrease in AFP levels, there still might be a risk of recurrence, especially in patients who have greater amplitude undulations. ${ }^{[8]}$

In addition, elevated AFP levels may be seen in some benign conditions including hepatic disorders (extrahepatic biliary atresia, neonatal hepatitis, acute and chronic viral hepatitis, fulminant acute hepatitis, liver cirrhosis, hepatic abscess), hereditary disorders (hereditary AFP persistence, ataxia telangiectasia, hereditary tyrosinemia type 1), systemic lupus erythematosis, Hirschsprung disease, pregnancy and infancy. ${ }^{[7]}$

In the literature, high AFP levels in different benign liver masses have been reported. ${ }^{[2-4]}$ Sari et al. ${ }^{[2]}$ reported elevated AFP levels in a 15-dayold boy with hemangioendothelioma. In this case, initial AFP level was $650 \mathrm{ng} / \mathrm{mL}$ (normal range for his age $88 \pm 87 \mathrm{ng} / \mathrm{mL}$ ). After high dose methylprednisolone treatment, AFP level was $54.7 \mathrm{ng} /$ $\mathrm{mL}$ (normal range for age $12.5 \pm 9.8 \mathrm{ng} / \mathrm{mL}$ ); and when he was 2-years-old, the serum AFP level was normal. Another case is our case, which is an 11-month-old boy. He was admitted to our hospital with complaints of irritability and painless abdominal mass. Imaging studies showed a large multicystic liver mass and serum AFP level was 3829 $\mathrm{ng} / \mathrm{mL}$. The fine-needle aspiration biopsy suggested the lesion to be hepatoblastoma; therefore, he received preoperative chemotherapy. At the end of the preoperative chemotherapy, the tumor size and AFP level decreased. A right hepatectomy was performed. The pathologic examination of the specimen revealed mesenchymal hamartoma. ${ }^{[3]}$ The other case was focal nodular hyperplasia of the liver and elevated AFP level in an infant with isolated hemihyperplasia which was reported by Demir et al. ${ }^{[4]}$

Herein, we aimed to evaluate the elevated AFP levels in benign/borderline liver masses in this study. There were three boys and two girls with a median age of 6 months (range 1-12 months) at the time that the liver mass was diagnosed. At the time of the diagnosis, AFP levels were between 123 U/L and $4905 \mathrm{U} / \mathrm{L}$ (median $2736 \mathrm{U} / \mathrm{L}$ ). The masses ranging from $11 \mathrm{~mm}$ to $28 \mathrm{~cm}$ were detected during screening studies. Two patients were diagnosed with hemangioendothelioma, 1 patient had mesenchymal hamartoma of the liver, one patient had hemangioma and another one was diagnosed with focal nodular hyperplasia through histopathological examination. One of the patients with hemangioendothelioma was referred to another center for liver transplantation, but the other one died during the early follow-up while under steroid treatment. In the patient who had hamartoma with high AFP levels, which was previously reported, ${ }^{[3]}$ fine needle aspiration biopsy revealed malign cells; therefore, the patient was thought to have primary liver malignancy and cisplatin-adriamicin regimen was started. After the treatment, the mass size in the liver had shrunk and totally excised surgi- 
cally. With the pathologic evaluation after the operation, it is determined that the first assessment of the patient was wrong and the true diagnose was hamartoma. Thus, the treatment of the patient was stopped and the patient is currently disease-free and under follow-up. The patients with hemangioma and focal nodular hyperplasia are still under follow-up without receiving any treatment.

\section{CONCLUSION}

In conclusion, mildly or moderately high AFP levels can be seen in the non-malign hepatic masses and they can wrongly suggest malignant liver tumors.

\section{REFERENCES}

1. Olson TA, Schneider DT, Perlman EJ. Germ cell tumors. In: Pizzo PA, Poplack DG, editors. Principles and practice of pediatric oncology. $5^{\text {th }}$ ed. Philadelphia: Wolters Kluwer/Lippincott Williams \& Wilkins; 2011. p. 1045-67.

2. Sari N, Yalçin B, Akyüz C, Haliloglu M, Büyük- pamukçu M. Infantile hepatic hemangioendothelioma with elevated serum alpha-fetoprotein. Pediatr Hematol Oncol 2006;23(8):639-47. CrossRef

3. Unal E, Koksal Y, Akcoren Z, Tavl L, Gunel E, Kerimoglu U. Mesenchymal hamartoma of the liver mimicking hepatoblastoma. J Pediatr Hematol Oncol 2008;30(6):458-60. CrossRef

4. Demir HA, Varan A, Akçören Z, Haliloglu M, Büyükpamukcu M. Focal nodular hyperplasia of the liver and elevated alpha fetoprotein level in an infant with isolated hemihyperplasia. J Pediatr Hematol Oncol 2008;30(10):775-7. CrossRef

5. Wu JT, Book L, Sudar K. Serum alpha fetoprotein (AFP) levels in normal infants. Pediatr Res 1981;15(1):50-2.

6. Schneider DT, Calaminus G, Göbel U. Diagnostic value of alpha 1-fetoprotein and beta-human chorionic gonadotropin in infancy and childhood. Pediatr Hematol Oncol 2001;18(1):11-26. CrossRef

7. Olson TA. Hepatic Tumors. In: Lanzkowsky P, editors. Manual of pediatric hematology and oncology. 5th ed. Amsterdam: Academic press; 2011. p. 796-805.

8. Aydin GB, Hayran M, Büyükpamukçu M. Undulant course of AFP: a sign of tumor activation or not? Pediatr Hematol Oncol 2009;26(1):30-5. CrossRef 